\title{
PEMANFAATAN SLUDGE INSTALASI PENGOLAHAN AIR LIMBAH INDUSTRI PULP DAN KERTAS SEBAGAI BAHAN BAKU BIOETANOL
}

\author{
Rina S. Soetopo *, Sri Purwati, Yusup Setiawan, Susi Sugesty \\ Balai Besar Pulp dan Kertas, Jl. Raya Dayeuhkolot No. 132 Bandung \\ *rnsusilowati@yahoo.com
}

Diterima : 27 September 2012, Revisi akhir : 24 Desember 2012

\begin{abstract}
UTILIZATION OF SLUDGE FROM WASTEWATER TREATMENT PLANT OF PULP AND PAPER INDUSTRY AS BIOETHANOL RAW MATERIAL
\end{abstract}

\begin{abstract}
Investigation on utilization of sludge waste from Wastewater Treatment Plant (WWTP) of pulp and paper mill for bioethanol feedstock in a batch system at laboratory scale has been carried out. Experiments were conducted in three phases, namely the hydrolysis process; the fermentation process by Saccharomyces cerevisiae and the simultaneous saccharification-fermentation experiments. Ethanol concentration produced was tested by the HPLC method. Results show that t primary sludge from paper mills made from virgin pulp (sludge A) and primary sludge from pulp and paper made from raw wood (sludge B) at a $2 \%$ total solids having potential as raw material for bioethanol. The optimum conditions of the hydrolysis process of sludge A and sludge B is obtained from the sludge solids content of $6 \%$, with the addition of cellulase of 9 FPU/g cellulose and beta-glucosidase of 6.7 IU/FPU for the incubation time of 48 hours producing the reducing sugar content of $31.3 \%$ and $36.2 \%$ with the hydrolysis efficiency of $64 \%$ and $71 \%$ respectively. On the SSF process conditions at pH of 4.5 , temperature of $28^{\circ} \mathrm{C}$ for 96 hours, the sludge substrate A can produce ethanol with the concentration of $3.45 \%$ and the process efficiency of $72.5 \%$ and the sludge substrate B can produce ethanol with the concentration of $2.89 \%$ and the process efficiency of $60.8 \%$.
\end{abstract}

Keywords: bioethanol, cellulase, hydrolysis, fermentation, Saccharomyces cerevisiae, sludge

\begin{abstract}
ABSTRAK
Penelitian pemanfaatan sludge Instalasi Pengolahan Air Limbah (IPAL) industri pulp dan kertas untuk bahan baku bioetanol dengan sistem batch pada skala laboratorium telah dilakukan. Percobaan dilakukan dalam tiga tahapan yaitu - proses hidrolisis dengan enzim; proses fermentasi dengan Saccharomyces cerevisiae dan proses sakarifikasi-fermentasi serentak (SFS) pada satu reaktor. Kadar etanol yang dihasilkan diuji dengan metode HPLC. Hasil percobaan menunjukkan bahwa dari 4 jenis sludge yang diteliti, sludge primer dari pabrik kertas berbahan baku virgin pulp (sludge A) dan dari pabrik pulp dan kertas berbahan baku kayu (sludge B) berpotensi sebagai bahan baku bioetanol. Kondisi optimum percobaan proses hidrolisis sludge A dan sludge B diperoleh dari perlakuan dengan kadar padatan $6 \%$, dosis selulase $9 \mathrm{FPU} / \mathrm{g}$ selulosa; dosis beta glukosidase $6,7 \mathrm{IU} / \mathrm{FPU}$ dengan lama inkubasi 48 jam, masing-masing menghasilkan kadar gula pereduksi sebesar 31,3\% dan 36,2\% dengan efisiensi hidrolisis $64 \%$ dan $71 \%$. Pada percobaan SFS dengan kondisi proses $\mathrm{pH} 4,5$ pada suhu $28^{\circ} \mathrm{C}$ selama 96 jam, substrat sludge A dapat menghasilkan etanol sebesar 3,45\% dengan efisiensi proses $72,5 \%$ dan substrat sludge B dapat menghasilkan etanol sebesar 2,89\% dengan efisiensi proses $60,8 \%$.
\end{abstract}

Kata kunci: bioetanol, selulase, hidrolisis, fermentasi, Saccharomyces cerevisiae, sludge 


\section{PENDAHULUAN}

Industri pulp dan kertas dikelompokan menjadi industri pulp dan kertas terpadu dan non terpadu sebagai industri pulp atau industri kertas saja. Industri pulp dan kertas terpadu menggunakan bahan baku kayu, sedangkan-industri kertas menggunakan bahan baku virgin pulp atau bahan baku kertas bekas. Dari proses produksinya dihasilkan limbah lumpur (sludge) yang cukup besar, terutama dari Instalasi Pengolahan Air Limbah (IPAL). Jumlah produksi sludge IPAL tersebut sangat besar berkisar antara 2-10\% (kadar air 70\%) dari kapasitas produksinya (Purwati dkk., 2006). Sludge IPAL dari industri pulp dan kertas, umumnya terdiri dari sludge primer yang berasal dari IPAL sistem fisika-kimia berupa serat halus dan sludge sekunder yang berasal dari IPAL sistem biologi berupa biomassa mikroba.

Berdasarkan komponennya, sludge primer banyak mengandung bahan organik terutama selulosa. Achira dkk. (2009) menjelaskan bahwa komposisi sludge primer IPAL dari industri pulp dan kertas terdiri dari selulosa 21,1\%, hemiselulosa $4,1 \%$, lignin $13 \%$ dan abu $46,5 \%$. Sedangkan menurut Harmsen dkk. (2010), dan Petrova dan Ivanova (2010), komposisi sludge IPAL dari industri pulp dan kertas mengandung selulosa sekitar 8-15\%. Zhiliang dan Lynd (2007) juga menjelaskan bahwa sebagian besar sludge IPAL industri pulp dan kertas mengandung glukan $54-55 \%$, xilan $9,0 \%$ dan manan $2 \%$.

Pemanfaatan biomassa selulosa sebagai sumber alternatif bahan baku bioetanol generasi kedua sudah mulai banyak dilakukan. Biomassa selulosa dari sludge IPAL industri pulp dan kertas dapat dimanfaatkan untuk memproduksi bioetanol dengan proses sakarifikasi-fermentasi (Hu dkk., 2008), dan dengan proses hidolisisfermentasi (Knutson dkk., 2007). Selulosa bagas dapat dimanfaatkan untuk produksi etanol melalui proses Sakarifikasi Fermentasi Serentak (SFS) dengan enzim xilanase dan ragi Saccharomyces cerevisiae (Samsuri, 2007). Pada 11 industri pulp dan kertas di Amerika dengan kapasitas produksi 325-2740 ton/hari yang menghasilkan sludge IPAL sekitar 9-170 ton/hari dapat menghasilkan etanol sebesar $0,1-3,2$ juta galon per tahun atau $80 \%$ dari perhitungan secara teoritis (Kerstetter dkk., 1997).

Pada umumnya, bioetanol diproduksi dengan cara fermentasi gula menggunakan bantuan aktivitas mikroorganisme. Bagi bahan baku organik kompleks seperti selulosa, hemiselulosa, dan organik kompleks lainnya perlu dihidrolisis lebih dahulu secara kimia ataupun enzimatis. Teknologi proses hidrolisis secara kimia pada dasarnya kurang ramah lingkungan, sehingga proses hidrolisis banyak dikembangkan dengan menggunakan enzim xilanase dan selulase masing-masing merupakan enzim hidrolisis hemiselulosa dan selulosa menjadi xilosa dan glukosa yang merupakan bahan baku etanol (Samsuri dkk., 2007).

Atas dasar komponen selulosa dalam sludge IPAL yang masih cukup tinggi, maka sludge IPAL industri pulp dan kertas memiliki potensi untuk dimanfaatkan sebagai bahan baku bioetanol yang memiliki nilai ekonomi tinggi, juga merupakan salah satu alternatif dalam mengatasi masalah lingkungan. Hambatan pemanfaatan sludge IPAL industri pulp dan kertas sebagai bioetanol adalah kompleksnya komponen organik yang terkandung dalam sludge, sehingga perlu dilakukan proses hidrolisis secara efektif. Selain itu, ketersediaan sludge IPAL di industri umumnya terdiri dari gabungan sludge primer dan sekunder, sehingga perlu dikaji pula pengaruh sludge gabungan tersebut terhadap proses konversi sludge menjadi bioetanol.

Sehubungan dengan uraian di atas, penelitian ini dilakukan dengan tujuan untuk mengetahui potensi limbah sludge industri pulp dan kertas sebagai bahan baku bioetanol dan artikel ini berisi hasil penelitian pemanfaatan sludge IPAL industri pulp dan kertas sebagai bahan baku bioetanol.

\section{BAHAN DAN METODE}

\section{Bahan}

Bahan yang digunakan dalam penelitian ini adalah empat jenis sludge IPAL yang diperoleh dari 4 industri pulp dan kertas yang berbeda bahan baku yang digunakan, yaitu (1) sludge A berupa sludge primer dari industri kertas dengan bahan baku virgin pulp; (2) sludge B berupa sludge primer dari industri pulp dan kertas terpadu dengan bahan baku kayu; (3) sludge C berupa sludge primer dari industri kertas dengan bahan baku kertas bekas; (4) sludge D berupa sludge campuran primer dan sekunder dari industri pulp dan kertas terpadu dengan bahan baku kayu. -

Sludge primer diambil dari outlet clarifier primer dan sludge campuran primer dan sekunder diambil dari keluaran mesin press sludge pada 
sistem Instalasi Pengolahan Air Limbah (IPAL) dari setiap industri. Penyimpanan sampel dilakukan dalam cold storage $4^{\circ} \mathrm{C}$. Enzim yang digunakan pada penelitian ini adalah selulase yang memiliki aktivitas $6 \mathrm{FPU} / \mathrm{mL}$ dan beta glukosidase yang memiliki aktivitas $10 \mathrm{unit} / \mathrm{mL}$. Sebagai pengkondisi $\mathrm{pH}$ pada proses hidrolisis digunakan larutan penyangga fosfat, sedangkan ragi untuk fermentasi alkohol menggunakan $S$. cerevisiae.

\section{Peralatan}

Peralatan yang digunakan dalam penelitian dengan percobaan sistem batch ini adalah peralatan gelas untuk percobaan hidrolisis enzimatis dan fermentasi, inkubator goyang, autoclave, $\mathrm{pH}$ meter, magnetic stirrer, oven dan rangkaian alat distilasi, laminar air flow, cold storage, dan termometer. Peralatan yang digunakan untuk pengujian antara lain spektrofotometer dengan panjang gelombang 620 nm untuk uji gula pereduksi; AAS flame untuk uji beberapa logam berat dalam sludge yang terdiri dari timbal $(\mathrm{Pb}) 283,3 \mathrm{~nm}$, kadmium (Cd) 228,8 $\mathrm{nm}$, tembaga $(\mathrm{Cu}) 324,7 \mathrm{~nm}$, nikel $(\mathrm{Ni}) 232,0 \mathrm{~nm}$, seng (Zn) 213,9 nm; kromium (Cr) 357,9 nm; dan kobalt (Co) 240,7 nm; HPLC untuk analisis bioetanol dengan kondisi sebagai berikut: fase gerak $\mathrm{H}_{2} \mathrm{SO}_{4} \quad 0,008 \mathrm{~N}$; kolom aminex ${ }^{\circledR} \mathrm{HPX}$ $87 \mathrm{H}, 300 \mathrm{~mm} \times 7,8 \mathrm{~mm}$; refractive index detector; flow rate $1 \mathrm{~mL} / \mathrm{menit}$; volume injeksi $20 \mu \mathrm{L}$; suhu kolom $35^{\circ} \mathrm{C}$; dan back pressure 1553 psi.

\section{METODOLOGI PENELITIAN}

\section{Karakterisasi Sludge IPAL}

Terhadap sludge dari masing-masing industri dilakukan karakterisasi yang meliputi beberapa parameter yang berhubungan dengan potensi sebagai bahan baku bioetanol antara lain: kadar abu, lignin, holoselulosa, dan ekstraktif serta beberapa parameter logam berat yang meliputi timbal $(\mathrm{Pb})$, kadmium $(\mathrm{Cd})$, tembaga $(\mathrm{Cu})$, nikel (Ni), seng ( $\mathrm{Zn})$, kromium (Cr), dan kobalt (Co), yang pengujiannya menggunakan metode SNI tahun 2009.

\section{Tahapan Percobaan}

Secara garis besar, percobaan dilakukan dalam 3 tahap, yaitu (1) uji potensi sludge sebagai bahan baku etanol; (2) penentuan kondisi optimum proses hidrolisis sludge dan proses fermentasi gula sakarifikasi; (3) proses sakarifikasifermentasi serentak pada kondisi optimum.

Uji potensi dilakukan dengan cara melakukan hidrolisis enzimatis terhadap 4 jenis sludge pada kadar padatan 2\% dalam Erlenmeyer $250 \mathrm{~mL}$. Enzim yang digunakan adalah selulase dengan dosis $11 \mathrm{FPU} / \mathrm{g}$ selulosa, $\mathrm{pH}$ diatur pada kisaran 5,5 dengan penyangga fosfat. Uji ini dilakukan secara aseptik dalam inkubator goyang pada suhu $50^{\circ} \mathrm{C}$ selama $96 \mathrm{jam}$. Masing-masing uji dilakukan 3 replikasi dengan parameter pengamatan adalah gula pereduksi yang dianalisis dengan metode Somogyi Nelson menggunakan spektrofotometer UV-VIS pada panjang gelombang $620 \mathrm{~nm}$ (Lucy dan Nora, 2011). Sludge yang memberikan konsentrasi gula pereduksi tertinggi dengan efisiensi proses lebih besar dari $70 \%$ dianggap memiliki potensi untuk digunakan sebagai bahan baku etanol. Penentuan kondisi optimum hidrolisis selulosa dalam sludge dilakukan hanya terhadap satu sludge yang memiliki efisiensi sakarifikasi lebih besar dari $70 \%$ pada uji potensi di atas. Proses hidrolisis dilakukan dengan rancangan percobaan Rancangan Acak Lengkap (RAL) dengan 2 faktor perlakuan, yaitu :

1. Kadar padatan sludge, per dasar kering: $2 \%$, $4 \%, 6 \%, 8 \%$, dan 10\% (kisaran dewatering sludge)

2. Dosis selulase (FPU per g selulosa): $5,7,9$, 18, dan 27

Beta glukosidase ditambahkan sebanyak 6,7 IU/FPU terhadap semua perlakuan. Kondisi percobaan ditentukan berdasarkan kondisi optimum aktivitas selulase yaitu suhu $50^{\circ} \mathrm{C}$; $\mathrm{pH}$ 5,5; dan kecepatan pengadukan $110 \mathrm{rpm}$. Parameter pengamatan adalah konsentrasi gula pereduksi. Efisiensi hidrolisis dihitung dengan menggunakan persamaan 1 (Vertès dkk., 2010).

Percobaan penentuan kondisi optimum proses fermentasi hanya dilakukan terhadap cairan hasil proses hidrolisis sludge yang memiliki kadar gula

$$
\text { Efisiensi Hidrolisis }(\%)=\frac{\text { Glukosa yang Dihasilkan }(\mathrm{g})}{1,11 \times \text { Selulosa }(\mathrm{g})} \times 100 \%
$$


pereduksi tertinggi dengan menggunakan labu Erlenmeyer $250 \mathrm{~mL}$. Cairan tersebut ditambah $12,5 \%(\mathrm{v} / \mathrm{v})$ medium nutrisi yang komposisinya terdiri dari $0,5 \mathrm{~g} / \mathrm{L} \quad\left(\mathrm{NH}_{4}\right) \mathrm{HPO}_{4} ; 0,025 \mathrm{~g} / \mathrm{L}$ $\mathrm{MgSO}_{4} .7 \mathrm{H}_{2} \mathrm{O}$; dan $1 \mathrm{~g} / \mathrm{L}$ ekstrak ragi. Semua medium disterilisasi pada suhu $121^{\circ} \mathrm{C}$ selama 30 menit pada autoclave. Fermentasi dilakukan dengan menambahkan ragi $S$. cerevisiae yang telah diaklimatisasi terhadap gula hasil hidrolisis selulosa dalam sludge pada suhu $28^{\circ} \mathrm{C}$. Percobaan dilakukan dengan 2 faktor perlakuan, yaitu $\mathrm{pH}$ $(4,5 ; 5,0 ; 5,5 ; 6,0)$ dan lama inkubasi $(24 ; 48 ; 72$; $96 ; 120$ jam) dengan penambahan inokulum ragi S. cerevisiae sebanyak $10 \%$ (v/v) dengan jumlah sel $10^{6} / \mathrm{mL}$. Parameter pengamatan dilakukan terhadap kadar etanol yang dianalisis dengan HPLC. Setelah diperoleh kondisi optimum proses hidrolisis dan proses fermentasi, kemudian dilakukan fermentasi serentak pada satu reaktor.

\section{HASIL DAN PEMBAHASAN}

\section{Karakteristik Sludge IPAL}

Sludge industri pulp dan kertas yang digunakan untuk penelitian ini diutamakan dari sludge primer yang sebagian besar kandungan dari sludge tersebut merupakan senyawa organik selulosa. Kadar senyawa organik dalam sludge sangat bervariasi. Hal ini dapat dilihat dari hasil analisis kadar abu yang berkisar antara 3,10-39,63\%. Sludge yang digunakan tersebut adalah limbah serat yang dihasilkan dari pemisahan serat selulosa yang lolos dari pencucian pulp, mesin kertas, reject proses penyedian stok, unit pemulihan serat, dan hasil akhir pengolahan IPAL. Komponen sludge tersebut selain bahan serat, juga berupa bahan pengisi dan pengotor lainnya. Sludge tersebut baik jumlah maupun karakteristiknya sangat bervariasi tergantung dari bahan baku, proses pembuatan, dan produk yang dihasilkan.
Hasil analisis menunjukkan bahwa komponen sludge yang berasal dari IPAL industri pulp dan kertas terpadu terdiri dari lignin dengan kadar berkisar antara 3,24-4,27\% dan holoselulosa sekitar 48,99-93,26\%. Kandungan holoselulosa merupakan polisakarida yang terdiri dari selulosa dan hemiselulosa. Kandungan hemiselulosa yang berupa pentosan sekitar 4,25-16,32\%. Pada umumnya industri pulp di Indonesia menggunakan bahan baku kayudaun. Pulp dari kayudaun mengandung hemiselulosa yang kandungan pentosannya lebih banyak daripada heksosannya sehingga penentuan hemiselulosa berupa pentosan. Komponen-komponen sludge tersebut merupakan senyawa lignoselulosa yang berasal dari kayu sebagai bahan baku industri pulp dan kertas.

Berdasarkan data karakteristik sludge pada Tabel 1, menunjukkan bahwa sludge IPAL ini masih memiliki selulosa yang cukup tinggi terlihat dari kandungan holoselulosanya. Kandungan selulosa yang tinggi merupakan sumber utama pembentuk glukosa sebagai bahan yang akan dikonversi menjadi etanol melalui proses hidrolisis-fermentasi. Sedangkan rendahnya kandungan lignin dalam sludge merupakan faktor penunjang dalam pembentukan glukosa. Lignin merupakan komponen sludge yang berpotensi sebagai inhibitor pada proses hidrolisis selulosa secara enzimatis. Keberadaan lignin dalam sludge dapat menghambat dalam proses degradasi selulosa dan hemiselulosa menjadi glukosa. Oleh karena itu, bahan baku untuk pembuatan bioetanol sebaiknya tidak mengandung lignin (Anindyawati, 2009).

\section{Potensi Sludge Sebagai Bahan Baku Etanol}

Hasil perhitungan efisiensi hidrolisis pada uji potensi sludge dapat dilihat pada Gambar 1. Dari gambar tersebut dapat dilihat bahwa sludge

Tabel 1. Komposisi Sludge IPAL Industri Pulp dan Kertas

\begin{tabular}{cccccc}
\hline & \multicolumn{5}{c}{ Hasil Analisis } \\
\cline { 2 - 6 } Sludge & Abu, \% & Lignin, \% & Holoselulosa, \% & $\begin{array}{c}\text { Pentosan sbg } \\
\text { Hemiselulosa, \% }\end{array}$ & $\begin{array}{c}\text { Ekstraktif Alkohol } \\
\text { /Benzen, \% }\end{array}$ \\
\hline A & 21,96 & - & 77,70 & 4,25 & 3,07 \\
B & 3,10 & 3,24 & 93,26 & 16,32 & 2,08 \\
C & 39,63 & - & 61,01 & 5,72 & 4,81 \\
D & 31,65 & 4,27 & 48,99 & 4,45 & 7,18 \\
\hline
\end{tabular}




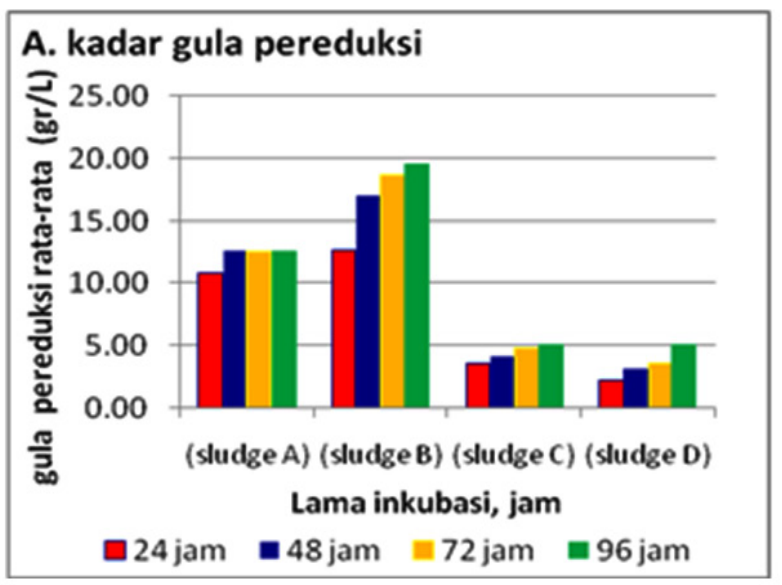

(A) Kandungan Gula Pereduksi

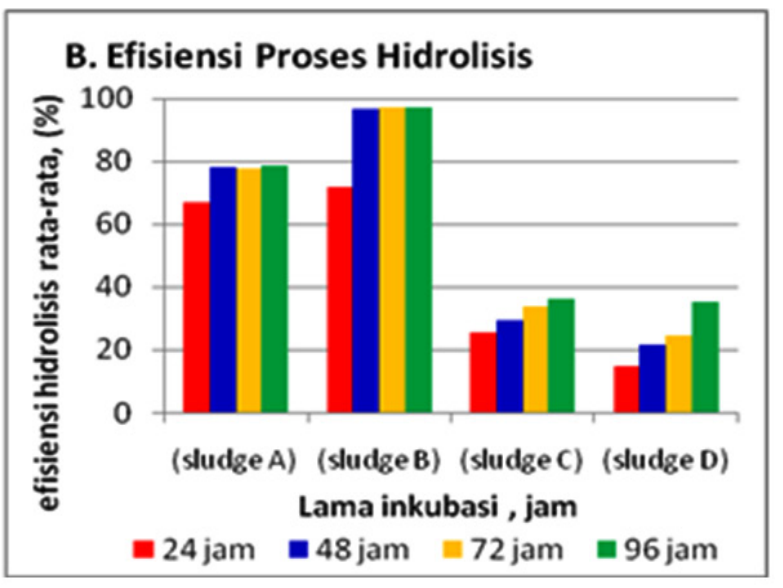

(B) Efisiensi Hidrolisis Selulosa

Gambar 1. Hasil Uji Potensi Sludge IPAL Industri Pulp dan Kertas

A dan sludge B memiliki efisiensi hidolisis lebih besar dari $70 \%$. Sludge A adalah sludge primer yang berasal dari pabrik kertas berbahan baku virgin pulp, sedangkan sludge $\mathrm{B}$ adalah sludge primer yang berasal dari pabrik pulp dan kertas berbahan baku kayu. Sejalan dengan karakteristik masing-masing sludge, menunjukkan bahwa sludge A dan sludge B memiliki potensi lebih baik dibandingkan sludge $\mathrm{C}$ dan sludge $\mathrm{D}$. Kadar glukosa dari hasil hidrolisa pada sludge A dan B berkisar antara 10-20\%, sedangkan sludge $\mathrm{C}$ dan D hanya sekitar $2-5 \%$ saja. Hal ini dikarenakan kadar selulosa yang terkandung dalam sludge A dan sludge B yang jauh lebih tinggi. Demikian pula dengan perhitungan efisiensi hidrolisis pada sludge A dan sludge B mencapai lebih besar dari $70 \%$, yang jauh lebih tinggi dari sludge $\mathrm{C}$ dan sludge D yang lebih kecil dari 40\%. Berdasarkan hasil uji potensi ini, maka untuk percobaan selanjutnya hanya menggunakan sludge A dan sludge $\mathrm{B}$.

Ditinjau dari kadar gula pereduksi yang dihasilkan dari masing-masing perlakuan inkubasi, menunjukkan bahwa pada proses hidrolisis sludge A, lama inkubasi 48 jam, 72 jam, dan 96 jam cenderung tidak berbeda nyata yaitu pada kisaran 12,51-12,67 g/L, demikian pula halnya pada proses hidrolisis sludge $\mathrm{B}$, perlakuan inkubasi sampai 96 jam menunjukkan kecenderungan yang tidak berbeda nyata, yaitu pada kisaran 17,05-19,04 g/L. Atas dasar hal tersebut, maka untuk percobaan proses hidrolisis sludge A dan sludge B selanjutnya dilakukan pada lama inkubasi 48 jam.

\section{Hidrolisis Selulosa secara Enzimatis}

\section{Penentuan Kondisi Hidrolisis}

Berdasarkan hasil uji potensi sludge, sludge A dan sludge B memiliki potensi sebagai bahan baku bioetanol. Selanjutnya, terhadap salah satu dari sludge tersebut dilakukan penentuan kondisi hidrolisis sludge yang diwakili oleh sludge A. Perlakuan percobaan telah dilakukan dengan variasi kadar padatan sludge A, yaitu antara $2 \%$ sampai $10 \%$ dengan penambahan selulase dan beta glukosidase. Hasil percobaan dapat dilihat pada Gambar 2.

Berdasarkan uji statistik univarian dengan program SPSS, menunjukkan bahwa variasi kadar padatan (TS) sludge A berpengaruh nyata terhadap kadar gula pereduksi sebagai produk hasil proses hidrolisis. Semakin tinggi kadar padatan sludge A dari 2\% sampai 6\% menghasilkan kadar gula pereduksi yang makin tinggi dengan kisaran rata-rata 9,3 g/L sampai 25,1 g/L (Gambar 2). Kondisi ini sejalan dengan jumlah selulosa yang dihidrolisis dalam sludge A yang makin besar sehingga gula pereduksi yang terbentuk makin besar pula. Namun, kadar gula pereduksi dari hasil hidrolisis sludge dengan kadar padatan $8 \%$ hingga $10 \%$ menunjukkan penurunan. Hal tersebut disebabkan oleh karena proses hidolisis sludge dengan TS di atas $8 \%$, tidak sesuai diperlakukan dengan metode shaker sebagai pengocokannya karena pencampuran antara sludge dengan enzim tidak dapat terjadi secara sempurna sehingga reaksi hidrolisis 


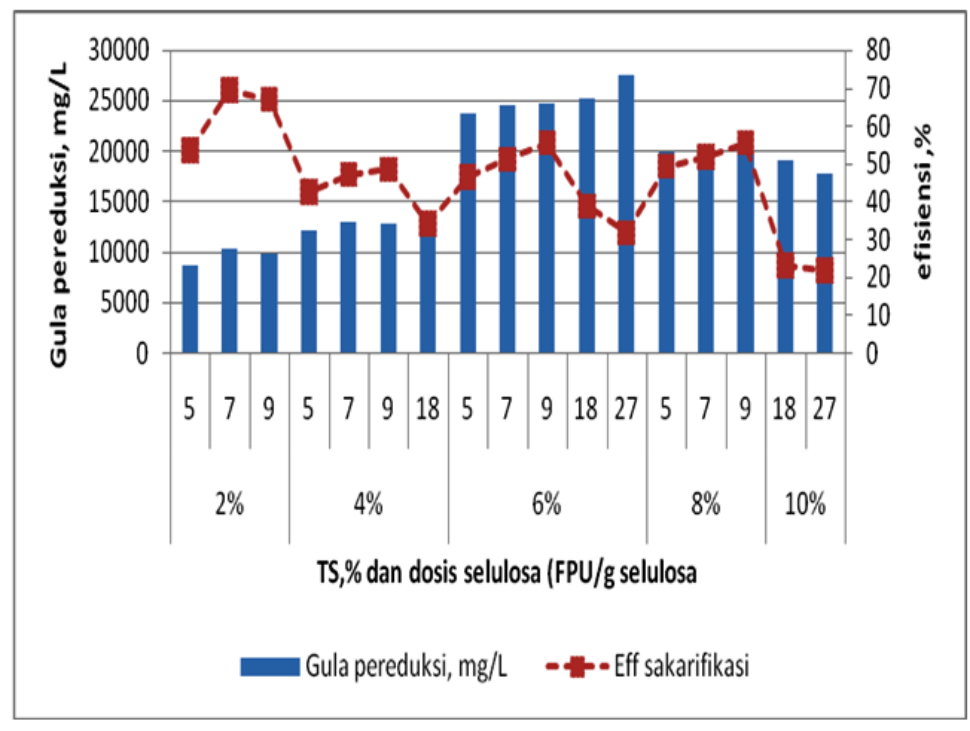

Gambar 2. Hasil Percobaan Hidrolisis Enzimatis Sludge A

menjadi kurang efektif. Hal tersebut sejalan dengan hasil penelitian yang dilakukan oleh Marquez dkk. (2008) yang menyatakan bahwa konsentrasi TS diatas 7,5\% (w/v), tidak efektif digunakan sebagai bahan baku untuk proses hidolisis enzimatis.

Berdasarkan perhitungan efisiensi hidrolisis, menunjukkan kecenderungan yang berbeda dari yang ditunjukkan oleh kadar gula pereduksi (Gambar 2). Perbedaan kadar padatan sludge A memberikan pengaruh berbeda nyata terhadap efisiensi hidrolisis, namun pada kadar TS sludge terendah $(2 \%)$ memberikan efisiensi hidrolisis tertinggi dan cenderung menurun terhadap kadar TS lainnya yang lebih tinggi (4-8\%). Keadaan ini menunjukkan kontradiksi antara perhitungan efisiensi dengan data analisis kadar gula pereduksi. Menurut Peng dan Chen (2011), hal ini dapat disebabkan oleh adanya penghambat dalam lumpur, adanya inaktivasi enzim dan terjadinya penurunan reaktivitas terhadap penambahan selulosa. Berdasarkan uji Duncan dari dua parameter pengamatan, yaitu kadar gula pereduksi dan efisiensi hidrolisis, maka kondisi sludge yang optimum diperoleh pada kondisi TS $8 \%$. Sedangkan berdasarkan pertimbangan kondisi di lapangan, umumnya proses dewatering sludge primer di industri pulp dan kertas, kadar TS sludge 6\% dapat dicapai tanpa penambahan bahan kimia.

Pada variasi dosis penambahan selulase pada proses hidrolisis menunjukkan kecenderungan bahwa dosis 5-9 FPU/(g selulosa) memberikan nilai peningkatan kadar gula pereduksi tertinggi
(Gambar 2), namun perhitungan secara statistik peningkatan tersebut tidak berbeda nyata. Berdasarkan hal tersebut, dosis selulase 7-9 FPU/(g selulosa) ditentukan sebagai kondisi optimum proses hidrolisis yang diaplikasikan pada percobaan selanjutnya, yaitu sakarifikasi fermentasi serentak.

\section{Aplikasi Kondisi Optimum Hidrolisis}

Kondisi optimum hidrolisis yang diperoleh diaplikasikan terhadap sludge yang berpotensi tinggi sebagai bahan baku bioetanol, yaitu sludge primer dari industri kertas berbahan baku pulp virgin (sludge $\mathrm{A}$ ) dan sludge primer dari industri pulp dan kertas terpadu berbahan baku kayu (sludge B). Proses hidrolisis enzimatik terhadap kedua sludge tersebut dilakukan pada kondisi optimumnya, yaitu kadar padatan (TS) sludge $6 \%$, dosis selulase $9 \mathrm{FPU} / \mathrm{g}$ selulosa dan beta glukosidase 6,7 IU/FPU dengan waktu inkubasi 48 jam. Tabel 3 menunjukkan bahwa kedua sludge A dan B cukup potensial untuk digunakan sebagai bahan baku bioetanol yaitu mencapai efisiensi lebih dari $60 \%$. Dari masing-masing sludge dapat dihasilkan kadar gula pereduksi $31,3 \mathrm{~g} / \mathrm{L}$ dan efisiensi hidolisis $64 \%$ untuk sludge A, sedangkan sludge B menghasilkan kadar gula pereduksi 36,2 $\mathrm{g} / \mathrm{L}$ dan efisiensi $71 \%$. Efisiensi hidrolisis yang dicapai dalam penelitian ini menunjukkan kecenderungan yang relatif sama dengan hasil penelitian yang dilakukan oleh Peng (2011) dan Marquez dkk. (2008). 
Tabel 3. Aplikasi Kondisi Optimum Proses Hidrolisis pada TS 6\%

\begin{tabular}{lcc}
\hline $\begin{array}{l}\text { Jenis } \\
\text { Sludge }\end{array}$ & $\begin{array}{c}\text { Gula Pereduksi } \\
\text { Rata-rata (g/L) }\end{array}$ & $\begin{array}{c}\text { Efisiensi } \\
\text { Hidrolisis (\%) }\end{array}$ \\
\hline Sludge A & 31,3 & $64 \%$ \\
Sludge B & 36,2 & $71 \%$ \\
\hline
\end{tabular}

Hasil penelitian Peng (2011) dengan menggunakan bahan baku paper sludge dengan konsentrasi 40,8 $\mathrm{g} / \mathrm{L}( \pm 4,1 \%)$ dengan waktu inkubasi $82,7 \mathrm{jam}$ dan dosis selulase $18 \mathrm{FPU} / \mathrm{g}$ selulosa dapat mencapai tingkat hidrolisis $82,1 \%$. Selain itu, hasil penelitian Marquez dkk. (2008) menjelaskan bahwa recycle paper sludge dengan total padatan 3\% (lama hidrolisis: 72 jam dan 144 jam) dan 7,5\% (lama hidrolisis: 120 jam) dengan suhu $35^{\circ} \mathrm{C}$ masing-masing dapat mencapai $100 \%$ dan $92 \%$. Sebagai pembanding, pembuatan etanol dari bahan baku jagung telah dilakukan oleh Llyod dan Wyman (2005), dengan kadar total padatan $1 \%$, dosis selulase $60 \mathrm{FPU} /$ g.selulosa dan waktu 72 jam telah diperoleh efisiensi berkisar 78,9-93\%. Dibandingkan dengan hasil yang diperoleh dari penelitian sebelumnya, efisiensi hidrolisis penelitian ini masih lebih rendah, namun demikian dapat berlangsung dengan waktu inkubasi lebih singkat dan dengan dosis selulase lebih rendah serta berlangsung pada kadar padatan sludge yang lebih tinggi.

Berdasarkan karakteristik bahan, sludge IPAL sebagai limbah industri pulp dan kertas yang merupakan senyawa lignoselulosa generasi kedua dari hasil penelitian ini cukup prospektif dimanfaatkan sebagai bahan baku bioetanol. Peningkatan efisiensi masih bisa dilakukan dalam suatu kondisi proses untuk mengoptimasi beban enzim melalui perlakuan terhadap substrat dan penghomogenan campuran dalam suatu reaktor kontinyu.

\section{Kondisi Optimum Proses Fermentasi}

Proses fermentasi dapat dilakukan dengan menggunakan ragi dari berbagai spesies yang salah satunya adalah $S$. cerevisiae. Ragi ini banyak digunakan untuk fermentasi alkohol dari berbagai jenis biomassa dalam berbagai kondisi fermentasi. Penggunaan spesies ragi yang berbeda dalam produksi bioetanol sangat berpengaruh terhadap konsentrasi bioetanol yang dihasilkan. Selain itu, konsentrasi bioetanol yang dihasilkan sangat dipengaruhi oleh suhu, $\mathrm{pH}$, sumber karbon, sumber nitrogen, dan waktu inkubasi dari masing masing ragi selama fermentasi (Anindyawati, 2009).

Dalam penentuan kondisi optimum proses fermentasi, digunakan substrat gula hasil hidrolisis dari sludge A. Gambar 3 menunjukkan bahwa kadar etanol yang dihasilkan dari proses fermentasi terhadap produk hidrolisis sludge A pada $\mathrm{pH} 4,0$ dan $\mathrm{pH} 4,5$ cenderung tidak berbeda, yaitu masing-masing berturut-turut berada pada kisaran $0,62-2,47 \%$ dan $0,84-3,38 \%$. Sedangkan pada $\mathrm{pH} 5,0 ; 5,5$; dan 6,0 masing-masing menunjukkan kadar etanol yang lebih rendah, yaitu berturut-turut $0,25 \%-1 \% ; \quad 0,07 \%-0,3 \%$ dan $0,035-0,13 \%$. Berdasarkan hasil percobaan

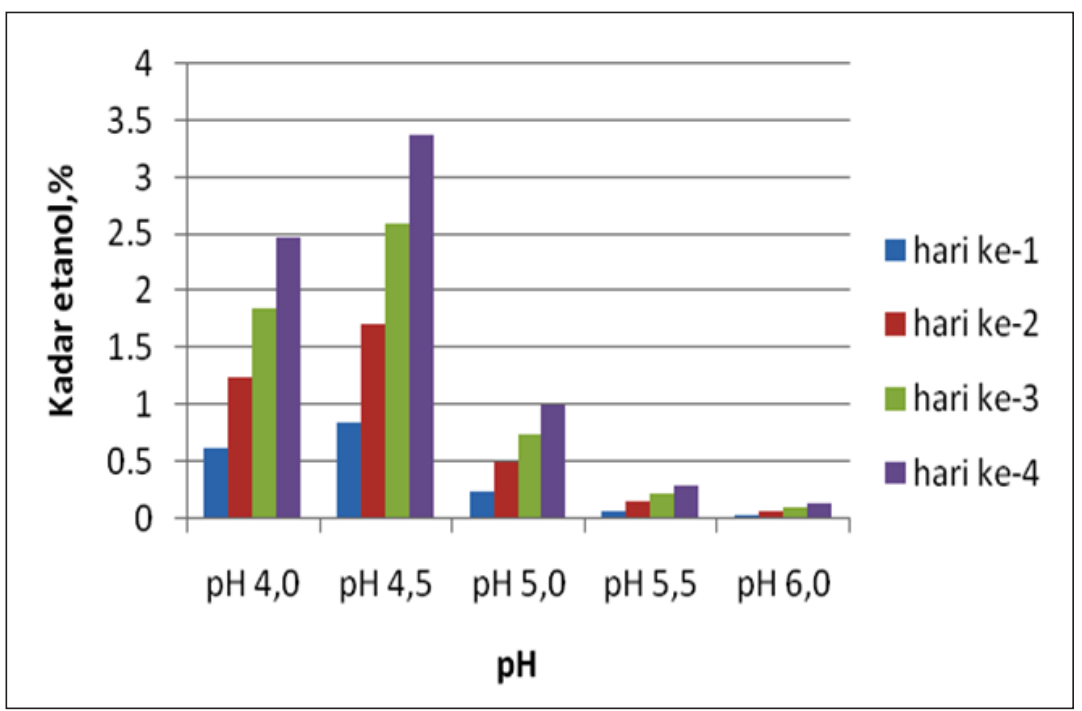

Gambar 3. Data Fermentasi Glukosa dari Sludge A 


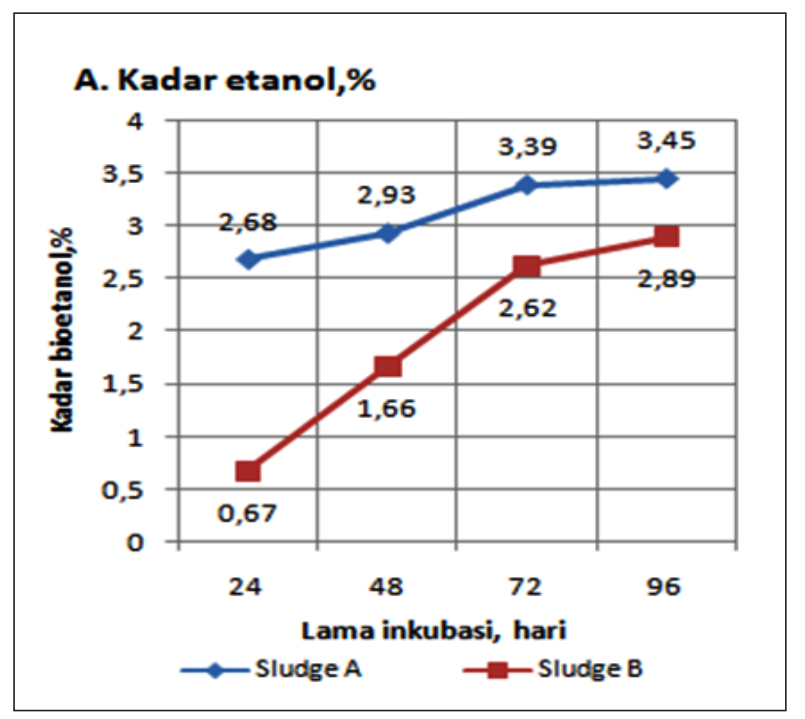

\section{B. Efisiensi Proses SSF}
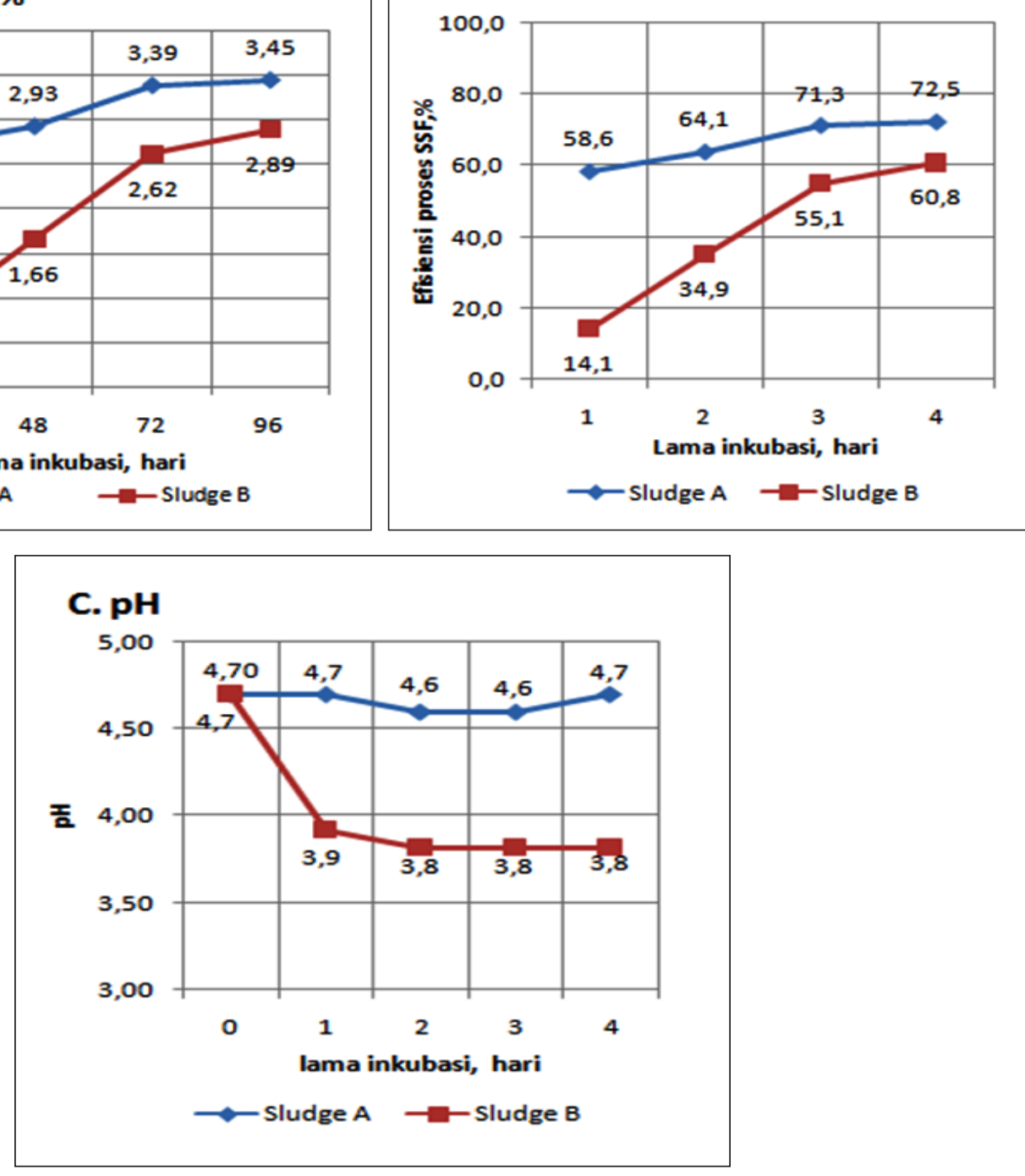

Gambar 4. Hasil Proses SSF (A. kadar etanol, B. efisiensi proses, dan C. perubahan pH)

tersebut, dapat disimpulkan bahwa $\mathrm{pH}$ optimum untuk proses fermentasi alkohol dengan $S$. cerevisiae adalah $\mathrm{pH} 4,5$, baik yang berlangsung dengan lama inkubasi 24 jam (hari ke-1) sampai 96 jam (hari ke-4). Ditinjau dari lama waktu inkubasi menunjukkan kecenderungan makin lama inkubasi hingga 96 jam memberikan hasil terbaik yang ditetapkan sebagai kondisi optimum.

\section{Sakarifikasi-Fermentasi Serentak (SSF)}

Saat ini, pembuatan bioetanol banyak dikembangkan dengan menggunakan metode proses Simultaneous Saccharification and Fermentation (SSF) atau Sakarifikasi dan Fermentasi Serentak (SFS) karena dilakukan dalam satu reaktor sehingga lebih efisien. Reaktor proses hidrolisis diatur pada kondisi optimum, polisakarida secara enzimatis didegradasi menjadi monosakarida yang kemudian dapat langsung difermentasi oleh $S$. cerevisiae. Selulase digunakan untuk memecah selulosa menjadi glukosa yang kemudian difermentasi oleh $S$. cerevisiae menjadi alkohol dan karbondioksida.

Saccharomyces cerevisiae yang digunakan telah mengalami aklimatisasi terhadap media gula pereduksi secara bertahap selama 2 minggu. Jumlah $S$. cerevisiae yang digunakan untuk proses SSF adalah $5.10^{6} / \mathrm{mL}$. Hasil percobaan proses SFS dapat dilihat pada Gambar 4.

Pada proses ini terjadi perubahan $\mathrm{pH}$, yang menunjukkan adanya reaksi aktivitas $S$. cerevisiae. Perubahan $\mathrm{pH}$ pada percobaan yang menggunakan substrat sludge A menunjukkan 
ada sedikit penurunan yaitu dari $\mathrm{pH} 4,7$ ke 4,6. Perubahan tersebut terjadi setelah inkubasi 48 jam. Lain halnya dengan perubahan $\mathrm{pH}$ pada percobaan yang menggunakan substrat sludge $\mathrm{B}$ menunjukkan adanya penurunan yang signifikan yaitu dari $\mathrm{pH} 4,7 \mathrm{ke} 3,8$. Adanya penurunan $\mathrm{pH}$ tersebut disebabkan oleh terbentuknya asam karbonat dan asam-asam organik lainnya selama proses sakarifikasi-fermentasi (Li, 2011). Adanya perbedaan penurunan $\mathrm{pH}$ pada percobaan yang menggunakan substrat sludge A dengan sludge B disebabkan sludge A berasal dari pabrik kertas yang memiliki kadar abu lebih tinggi, yaitu $21,96 \%$, yang berarti mengandung kadar anorganik yang kemungkinan dapat menetralisir pembentukan asam yang terbentuk saat proses sakarifikasi-fermentasi (Li, 2011), sedangkan sludge $\mathrm{B}$ berasal dari pabrik pulp dan kertas yang memiliki kadar abu rendah, yaitu 3,1\%, sehingga kandungan anorganiknya tidak cukup sebagai penetralisir asam-asam yang terbentuk saat proses sakarifikasi-fermentasi.

Kadar etanol yang dihasilkan dari proses SFS dengan substrat sludge A berkisar pada 2,68\% $3,45 \%$, yang menunjukkan lebih tinggi dibanding dengan menggunakan sludge $\mathrm{B}$ berkisar $0,67 \%$ - 2,89\% (Gambar 4). Kecenderungan sludge A lebih potensial dari sludge B tersebut sejalan dengan efisiensi proses SFS untuk masing-masing substrat, yaitu 58,6\%-72,5\% dengan substrat sludge A dan 14,1\%-60,8\% dengan subsrat sludge $\mathrm{B}$. Hal tersebut disebabkan oleh adanya penurunan $\mathrm{pH}$ selama proses yang mengakibatkan $\mathrm{pH}$ tidak optimum untuk proses fermentasi sludge B. Selain itu, pada sludge B terdapat adanya unsur-unsur penghambat yang berasal dari limbah industri pulp dan kertas yang kemungkinan berasal dari derivat lignin (Petro dkk., 2010).

\section{KESIMPULAN}

1. Karakteristik dari 4 (empat) jenis sludge primer IPAL industri pulp dan kertas yang berbeda produk dan bahan bakunya memiliki kandungan komponen organik dengan komposisi terdiri dari lignin berkisar 0,5-21,96\%; holoselulosa sekitar 70,70$77,70 \%$; $\alpha$-selulosa berkisar 28,79-80,15\%; hemiselulosa yang berupa pentosan sekitar 4,25-13,81\%.

2. Hasil uji potensi sludge menunjukkan bahwa sludge primer yang berasal dari pabrik kertas berbahan baku pulp virgin dan yang berasal dari pabrik pulp dan kertas berbahan baku kayu memberikan potensi sebagai bahan baku bioetanol-

3. Sludge dengan kadar padatan $6 \%$ merupakan kondisi terbaik untuk dimanfaatkan sebagai bahan baku bioetanol. Penambahan enzim terbaik pada proses hidrolisis adalah dosis selulase sebesar $9 \mathrm{FPU} / \mathrm{g}$ selulosa dan beta glukosidase 6,7 IU/FPU dengan lama inkubasi 48 jam pada $\mathrm{pH} 5,0$ dan suhu $50^{\circ} \mathrm{C}$. Hasil yang diperoleh untuk sludge A dari industri kertas adalah kadar gula pereduksi $31,3 \%$ dengan efisiensi $64 \%$, sedangkan untuk sludge B dari industri kertas pulp dan kertas memberikan kadar gula pereduksi $36,2 \%$ dengan efisiensi $71 \%$.

4. Proses SFS pada kondisi $\mathrm{pH} 4,5$ dan suhu $28^{\circ} \mathrm{C}$ selama 4 hari dengan penggunaan enzim selulase $9 \mathrm{FPU} / \mathrm{g}$ dan beta glukosidase 6,7 IU/ FPU serta ragi $S$. cerevisiae $5.10^{6} / \mathrm{mL}$ dapat menghasilkan kadar etanol tertinggi sebesar $3,45 \%$ dengan efisiensi $72 \%$ untuk sludge A, sedangkan untuk sludge B menghasilkan kadar etanol tertinggi 2,89\% dengan efisiensi $60 \%$.

\section{UCAPAN TERIMA KASIH}

Ucapan terima kasih disampaikan kepada Kementerian Riset dan Teknologi yang telah mendanai penelitian ini melalui Program Insentif Peningkatan Kemampuan Peneliti dan Perekayasa (PIPKPP) Tahun 2011.

\section{DAFTAR PUSTAKA}

Achira, M., 2009. "Bioconversion of paper mill lignocellulosic materials to Lactic Acid Using Cellulose Enzyme Complex and Microbial Cultures". Master of Science Thesis. Kansas State University. Manhattan. Kansas.

Anindyawati, T., 2009. Prospek Enzim dan Limbah Lignoselulosa untuk Produksi Bioetanol. Berita Selulosa. Volume 44. No.1. Juni. 49-56.

Harmsen, P. F. H., Huijgen, W. J. J., Bermúdez López, L.M., Bakker, R. R. C., 2010. Physical and Chemical Pretreatment Processes for Lignocellulosic Biomass. Food and Biobased Research. Wageningen. Nederland.

Hu. G., John A. H., Orlando, J. R., 2008. Feedstock Pretreatment Strategies for Producing Ethanol from Wood, Bark and Forest Residues. BioResources. 3(1). 270-294. 
Kerstetter J.D., Lynd, L., Lyford, K., South, C., 1997. Assessment of Potential for Conversion of Pulp and Paper Sludge to Ethanol Fuel in the Pacific Northwest. Cooperative Extension Energy Program. Washington.

Knutson, K., Ragauskas, A., Frederick Jr., W. J., Iisa, K., 2007. Production of Ethanol from Forest Residues. Georgia Institute of Technology, Atlanta, http://www.nt.ntnu.no/ users/skoge/prost/proceedings/aiche-2008/ data/papers/P138996.HTM. diakses tanggal 28 Oktober 2012.

Li, K., 2011. "Bioconversion of Pulp and Paper Mills Sludge and Prehydrolysate Stream into Ethanol and Cellulase Enzyme". dissertation. Auburn University. Alabama.

Lucy, A., Nora, I., 2011. Penentuan Lignin dan Kadar Glukosa dalam Hidrolisis Organosolv dan Hidrolisis Asam. Sains dan Terapan Kimia, Vol.5, No. 2, 140-150.

Marquez, S., Alves, L., Roseiro, J. C., G1'rio, F.M., 2008. Conversion of recycled paper sludge to ethanol by SHF and SSF using Pichia stipitis. Biomass and Bioenergy 32, $400-406$

Peng, L., Chen, Y., 2011. Conversion of Paper Sludge to Ethanol by Seperate Hydrolysis and Fermentation (SHF) Using Saccharomyces cerevisiae. Biomass and Bioenergy 35, 16001606
Petro, S., 2010. Fermentation In the Yeast Saccharomyces cerevisiae. http://phobos. ramapo.edu/ spetro/lab pdf/Fermlab.pdf, diakses 28 Oktober 2012

Petrova, P., Ivanova, V., 2010, Perspectives For The Production Of Bioethanol From Lignocellulosic Materials. Biotechnol. \& Biotechnol. Eq. 24/2010/Special Edition. 529-546.

Purwati, S., Soetopo, R. S., Setiaji, Setiawan, Y., 2006. The Potency and Alternative of Solid Waste Utilization from Pulp and Paper Industry. Journal of Cellulose. Vol. 41. No. 2., 67- 79 .

Samsuri, M., Gozan, M., Mardias, R., Baiquni, M., Hermansyah, H., Wijanarko, A., Prasetya, B., Nasikin., M., 2007. Pemanfaatan Selulosa Bagas Untuk Produksi Ethanol Melalui Sakarifikasi dan Fermentasi Serentak Dengan Enzim Xylanase. Makara, Teknologi, Vol. 11, No. 1, 17-24

Vertès, A. A., Qureshi, N., Blaschek, H. P., Yukawa, H., 2010. Biomass to Biofuels: Strategies for Global Industries. John Wiley \& Sons, Ltd. Publication.

Zhiliang, F., Lynd, L.R., 2007. Conversion of Paper Sludge to Ethanol. I: Impact of Feeding Frequency and Mixing Energy Characterization . Bioprocess Biosyst Eng. 30: $27-34$. 